\title{
Урахування особливостей біологічного розвитку юних спортсменок при підготовці у спортивних іграх
}

\author{
О. В. Маслова
}

Національний університет фізичного виховання і спорту України, Київ, Україна

\begin{abstract}
Резюме. Рассмотрены актуальные вопросы изучения особенностей тренировочного и соревновательного процесса юных спортсменок, специализирующихся в спортивных играх, $c$ целью обоснования необходимости учета биологических особенностей развития женского организма в системе подготовки спортсменок для повышения эффективности соревновательной деятельности и потенциального роста спортивной результативности при возможности предупреждения стрессовых ситуаций, профилактики переутомления и травматизма. Ключевые слова: спортсменки, баскетбол, гандбол, регби, спортивные игры, тренировочный процесс, тренировочные нагрузки, возраст менархе, биологическое развитии, физическое развитие, половое созревание.
\end{abstract}

Summary. The article reviews relevant issues of studying peculiarities of training and competitive process for young female athletes specializing in sports games with the aim to substantiate the necessity of considering biological features of female organism in the system of athletes preparation to increase the efficiency of competitive activity and potential growth of sports performance together with an opportunity to prevent stress situations, exhaustion and traumas.

Key words: young athletes, basketball, handball, rugby, sports, training process, training load, age at menarche, biological development, physical development, puberty.

Постановка проблеми та її зв'язок з важливими науковими чи практичними завданнями. У сучасному спорті вищих досягнень спостерігається конкурентна боротьба не тільки на спортивній арені, але й за ї̈ межами. Між системами підготовки в тому чи іншому виді спорту використовуються нові засоби і методи тренування, розглядаються різні сторони самої підготовки, активно застосовуються та впроваджуються результати наукових досліджень [3, 9].

Одним 3 таких напрямків $\epsilon$ жіночий спорт, який на сьогодні характеризується активним розвитком, відмінними особливостями і потенціалом представництва у спортивному товаристві. При цьому головною проблемою, що виникла в ході розвитку жіночого спорту, стало саме питання здійснення підготовки жінок-спортсменок за єдиним стандартом, ідентичним системі підготовки чоловіків [8, 9].

Аналіз останніх досліджень і публікацій. Аналіз науково-методичної літератури показав, що біологічні особливості жіночого організму, порівняно з чоловічим, зумовлюють відмінності психічних і функціональних реакцій на один і той же подразник, яким у спорті $\epsilon$ фрізичні та психологічні навантаження $[4,8]$. Саме тому виникає необхідність у диференціації системи підготовки спортсменок, 3 визначенням чітких принципів планування, побудови і проведення тренувального та змагального процесів [6].

Облік біологічних особливостей жіночого організму $є$ обгрунтуванням певного підходу в системі підготовки, незалежно від віку, кваліфрікації та спеціалізації спортсменок [7].

Зв'язок теми з важливими науковими чи практичними завданнями. Проведені нами дослідження виконано згідно зі «Зведеним планом НДР у сорері фізичної культури і спорту на 20102014 рр.» Міністерства освіти і науки, молоді та спорту України за темою 2.1.3: «Підвищення ефективності тренувального процесу та змагальної діяльності спортсменів високої кваліфікації у спортивних іграх» (номер держреєстрації 0106U010768).

Мета і завдання досліджень. На підставі вищевикладеного нами було сформульовано мету i завдання досліджень, вирішення яких здійснювалося в ході роботи. Мета дослідження - науково обгрунтувати шляхи підвищення ефективності підготовки спортсменок в ігрових видах спорту при урахуванні біологічних особливостей розвитку їх організму. Завдання дослідження:

1) вивчити актуальні питання системи підготовки жінок-спортсменок у категорії спортив- 
них ігор (на прикладі баскетболу, гандболу та регбі);

2) виявити і систематизувати функціональні особливості систем організму спортсменокпредставниць спортивної спеціалізації баскетбол, гандбол і регбі;

3) розширити уявлення про специфріку адаптаційних процесів жіночого організму до тренувальних і змагальних навантажень ігрових видів спорту (на прикладі баскетболу);

4) теоретично обгрунтувати необхідність врахування біологічних особливостей жіночого організму в системі підготовки спортсменок в ігрових видах спорту (на прикладі баскетболу).

Методи та організація досліджень. Дослідження проводились в природних умовах навчально-тренувального процесу команд високої кваліфікації, що спеціалізуються у спортивних іграх. Контингент обстежуваних спортсменок склали представниці баскетболу - 30 спортсменок, гандболу - 23 і регбі - 15 спортсменок. Спортивна кваліфікація дівчат на момент проведення дослідження: майстер спорту міжнародного класу -7 осіб, майстер спорту - 55, кандидат у майстри спорту -6 осіб.

Виклад основного матеріалу досліджень. Нами було проведено анкетне опитування спортсменок високої кваліфікації, які спеціалізуються у баскетболі, гандболі та регбі. Аналіз отриманих результатів дозволив встановити особливості тренувального та змагального процесів в цих видах спорту, а також дати характеристику біологічним особливостям організму спортсменок.

Встановлено, що вік, в якому переважно проводився набір і розпочинались систематичні заняття серед представниць спортивних ігор, 6-12 років. При цьому виявлено, що більшість спортсменок почали займатися в спортивних групах і секціях з видів спорту саме 3 6-7 років. Однак, згідно з даними науково-методичної літератури та рекомендацій провідних фахівців в області теорії і практики спортивних ігор, оптимальний вік для занять ігровими видами спорту 8-11 років. При цьому тижневий обсяг тренувального навантаження у більшості опитаних спортсменок у перші два роки початку занять спортом становив 9-10 годин на тиждень, що істотно перевищує допустимі норми відповідно для ДЮСШ, СДЮШОР.

Нами виявлено, що вік переходу спортсменок у спеціалізовані групи і класи з видів спорту складає 10-16 років, а для більшості спортсменок він дорівнював 12-13 рокам. Однак на сьогодні в баскетболі і гандболі $\epsilon$ випадки, коли перехід здійснюється, починаючи навіть з 10-річного віку, що не відповідає рекомендованим нормам документів, що регулюють роботу СДЮШОР та СШا.

При цьому обсяг тренувального навантаження для даних груп, як було нами встановлено, знаходився в межах 12-18 і більше годин на тиждень. Проте 3 опитування більшості спортсменок у віці 12-13 років, що займаються в спеціалізованих групах та класах, ми дізналися, що тижневий обсяг навантаження у них складав $18 \mathrm{i}$ більше годин на тиждень, при встановленій, згідно з віковими межами нормі - не більше 14 годин на тиждень.

Аналіз анкетних даних показав, що вік перших змагань серед опитаних спортсменок був від 8 до 14 років. Більшість опитаних спортсменок вказали на початок участі в змаганнях з 10-11 років. Вік переходу до складу профеесійних команд та включення в активний тренувальний i змагальний процеси, як було встановлено, починається вже 312 років, а у більшості спортсменок він склав 14-15 років.

Таким чином, слід зробити висновок, що на сьогодні спостерігається форсування системи підготовки спортсменок, які спеціалізуються у спортивних іграх. Скорочення початкового і попереднього базового періодів в системі багаторічної підготовки спортсменок; підвищення уваги до рівня фрізичної підготовленості; підготовка команди до ігрового сезону в найкоротші терміни; визначення пріоритету кожної гри, згідно 3 яким виключається можливість участі в юнацькому чемпіонаті з метою підготовки, контролю та підведення команди до змагань вищого рангу все це здійснюється без урахування можливості організму спортсменок переносити високі фрізичні і психологічні навантаження. У 13-15 років дівчата беруть участь у тренувальному та змагальному процесах поряд із висококваліфрікованими спортсменками, коли практично не враховуються їх вік і рівень розвитку організму.

При цьому забувають, що дані вікові межі відносяться до підліткового віку - надзвичайно важливого етапу становлення жіночого організму. Недарма його вважають критичним через прогресуючу активацію всіх параметрів фрізичного і статевого розвитку, ендокринного статусу, збільшення загальних енерговитрат і потреби організму в кисні, що в підсумку визначає рівень прояву працездатності дівчат $[2,7]$.

Нами був проведений аналіз медичних карт 30 спортсменок, які спеціалізуються у баскетболі i брали участь у анкетному опитуванні (рис. 1).

Отримані дані свідчать про те, що в різні вікові періоди спостерігається чергування приросту довжини або маси тіла. Причому в періоди після 


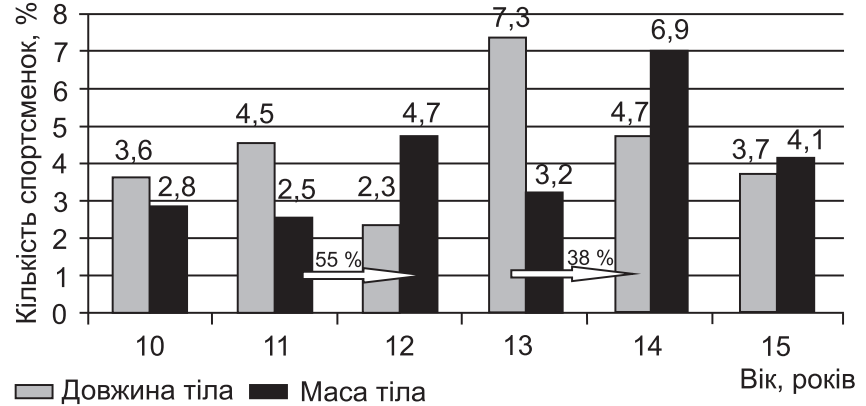

Рисунок 1 - Взаємозв'язок темпів фрізичного розвитку і статевого дозрівання опитаних спортсменок, що спеціалізуються у баскетболі $(\mathrm{n}=30)$

приросту маси тіла спостерігалося настання віку менархе у деяких з 30 спостережуваних спортсменок: у перший період - у $55 \%$ осіб з атлетичним соматотипом, і в другий період - у $38 \%$ спортсменок з астенічним соматотипом.

Проведені нами раніше дослідження взаємозв'язку темпів фрізичного розвитку і статевого дозрівання команди баскетболісток у віці 13-15 років дозволили дійти висновку, що вікові періоди становлення організму обстежуваних спортсменок у препубертатному і пубертатному періодах характеризуються динамікою зміни приросту довжини і маси тіла з настанням менархе після періоду приросту маси тіла (рис. 2) [4, 5].

Однак $\epsilon$ випадки, коли ще до настання менархе у дівчат відбуваються зміни гормонального фону організму, що набувають циклічного характеру, і $є$ ідентичними гормональним змінам протягом менструального циклу. Так звана прихована гормональна циклічність також має фрази, відповідні фазам менструального циклу залежно від концентрації естрогенної насиченості організму, яка визначається згідно з методом «френомен папороті».

Висновки і перспективи подальших досліджень. Урахування рівня біологічного розвитку спортсменок в їх спортивній діяльності дасть

\section{Література}

1. ПоплаВский Л. Ю. Баскетбол / Л. Ю. Поплавский. К.: Олимп. лит., 2004. - 448 с.

2. Богданова E. A. Гинекология детей и подростков / Е. А. Богданова. - М.: Мед. информ. агентство, 2000. $330 \mathrm{c}$.

3. Гуркин Ю. А. Гинекология подростков / Ю. А. Гуркин. - СПб: Фолиант, 2000. - С. 9-222.

4. Маслова О. В. Біологічне дозрівання та його роль у системі підготовки юних баскетболісток / О. В. Маслова // Педагогіка, психологія та медико-біологічні проблеми фрізичного виховання і спорту: зб. наук. пр. / за ред. С. С. Єрмаков. - 2005. - № 17. - С. 32-39.

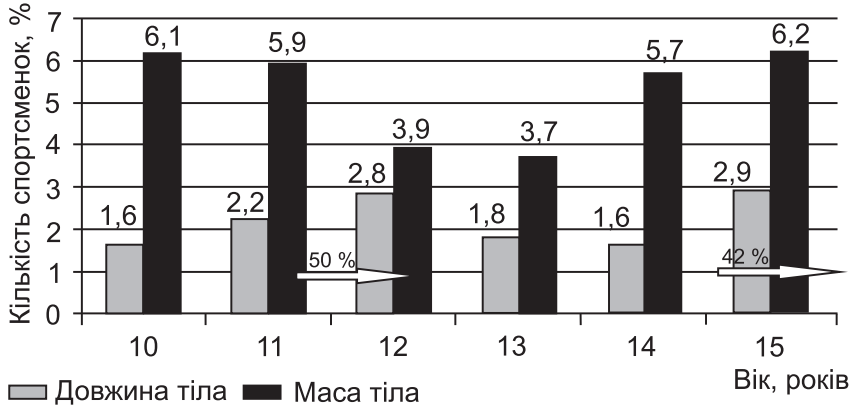

Рисунок 2 - Взаємозв'язок темпів фрізичного розвитку і статевого дозрівання опитаних спортсменок, що спеціалізуються у баскетболі, з настанням менархе $(\mathrm{n}=24)$

можливість тренеру визначити напрямок індивідуального підходу до кожної з дівчат команди окремо, що допоможе не тільки правильно застосовувати тренувальні навантаження і уникнути можливості отримання травм і перевтоми в періоди фрізіологічного перенапруження організму, а також - головне для спортсмена - підвищити спортивний результат.

Наступні наші дослідження будуть спрямовані на розробку та впровадження програм планування розвитку рухових якостей і побудови тренувального процесу на прикладі одного тренувального мезоциклу для команди юних спортсменок, які спеціалізуються у спортивних іграх.

Нами було встановлено, що дівчата одного паспортного віку відрізняються за рівнем біологічного дозрівання організму. Саме тому для дівчат зі встановленою менструальної функцією, а також для спортсменок 3 її відсутністю, але при наявності циклічних гормональних змін організму планування тренувального мезоциклу ми рекомендуємо на підставі фраз 28-денного менструального циклу, де мікроцикли відповідали фразам циклу. Такий підхід може дозволити прогресувати спортсменкам у подальші роки спортивної кар'єри, зберігаючи при цьому здоров'я і запобігаючи розвитку травм.

\section{References}

1. Poplavskiy L. Yu. Basketball / L. Yu. Poplavskiy. Kiev: Olympic literature, 2004. - $448 \mathrm{p}$

2. Bogdanova Ye. A. Pediatric and adolescent gynecology / Ye. A. Bogdanova - M.: Med. inform. agency, 2000. $330 \mathrm{p}$.

3. Gurkin Yu. A. Adolescent gynecology / Yu. A. Gurkin. - St. Petersburg: Foliant, 2000. - P. 9-222.

4. Maslova O.V. Biological maturation and its role in the system of young female basketball players training / O. V. Maslova // Pedagogy, psychology and medical-biological problems of physical education and sport: Coll. scientific papers / ed. S. S. Yermakov. - 2005. - N 17. - P. 32-39. 
5. Маслова О. В. Рівень біологічного розвитку - фрактор, який визначає прояв спеціальної працездатності та фрункціональних можливостей організму юних баскетболісток / О. В. Маслова // Молода спорт. наука України: зб. наук. пр. $з$ галузі фріз. культури та спорту. - 2006. № $10 .-$ С. $315-320$.

6. СпортиВні ігри: навч. посіб. для студ. факультетів фріз. культури пед. вищ. навч. закл.: у 2 т. / [Ж. Л. Козіна, Ю. М. Поярков, О. В. Церковна, В. О. Воробйова]; під ред. Ж. Л. Козіної. - Т. 1: Загальні основи теорії і методики спортивних ігор. - Х., 2010. - 200 с.

7. Шарапова О. В. Организация здоровья подростков как приоритетная задача отечественного здравоохранения / О. В. Шарапова, В. И. Орел, А. В. Ким // Здоровье подростков: руководство для врачей / [под ред. О. В. Шараповой]. - СПб., 2007. - С. 31-63.

8. Шахлина Л. Г. Функциональное состояние, физическая работоспособность квалифицированных спортсменок с учетом биологической цикличности женского организма / Л. Г. Шахлина // Наука в олимп. спорте. - 2004. № 1. - C. 84-91.

9. Шахлина Л. Г. Психофизиологические аспекты спортивной подготовки женщин / Л. Г. Шахлина // Наука в олимп. спорте. - 2006. - № 2. - С. 25-29.
5. Maslova O.V. The level of biological development as a factor that determines the manifestation of special performance and functional abiliities of young female basketball players / O.V. Maslova // Young sports science of Ukraine: Coll. scientific papers on the physical culture and sports. 2006. - N 10. - P. 315-320.

6. Sports Games: textbook for students of physical education universities: in two volumes / [Zh. L. Kozina, Yu. M. Poiarkov, O. V. Tserkovna, V. O. Vorobiova]; ed. by Zh. L. Kozina. - Vol. 1: General principles of the theory and methodology of sports games. - Kharkov, 2010. $200 \mathrm{p}$.

7. Sharapova O. V. Organization of adolescent health care as a priority of national health care system / O. V. Sharapova, V. I. Orel, A.V. Kim // Adolescent Health: Guide for Physicians / [ed. by O. V. Sharapova]. - Saint Petersburg, 2007. - P. 31-63.

8. Shakhlina L. G. Functional status, physical performance of elite athletes in view of the biological cycle of female organism / L. G. Shakhlina // Science in Olympic sports. 2004. - N 1. - P. 84-91.

9. Shakhlina L. G. Psychophysiological aspects of women sports training / L. G. Shakhlina // Science in Olympic sports. - 2006. - P. 25-29.

Надійшла 10.09.2013 